\title{
Experimental items
}

The full list of experimental items (and preceding context) is listed below, followed by a table with the average numerical rating for each item.

(X1) a. Emile regarde par la fenêtre et voit quelque chose d'étrange. Il dit :

'Emile looks through the window and sees something strange. He says:'

b. Qui sont les gens qui grimpent aux arbres dans le jardin? Who are the people who climb at.the trees in the garden

(X2) a. Marine s'inquiète. Elle pense que Léonie a des visions. Elle lui demande :

'Marine is worried. She thinks that Leonie is having visions. She asks her:'

b. Où vont les enfants que tu as vus ?

Where go the children that you have seen

(X3) a. Jules a reçu une enveloppe dans le courrier du matin. Il demande à son frère :

'Jules has received an envelope in the morning post. He asks his brother:'

b. Est-ce que le facteur a apporté ton paquet?

is-it that the postman has brought your parcel

(X4) a. Le fils d'Esmée lui demande de marcher plus vite. Elle s'énerve :

'Esmee's son asks her to walk faster. She looses patience:'

b. Pourquoi faut-il toujours se dépêcher pour tout? why must-it always oneself hurry for everything

(X5) a. Zelda et sa soeur sont à un concert. Zelda lui demande :

'Zelda and her sister are at a concert. Zelda asks her:'

b. Où est-ce que tu connais le gars qui joue du where is-it that you know the guy who plays PARTITIVE banjo ?

banjo

(X6) a. Le professeur Zébulon voit que son étudiant est occupé à lire un article sur un auteur qu'il pense connaître. Il lui demande :

'Zebulon's professor sees that his pupil is reading a paper on an author he thinks he knows. He asks him:'

b. De qui as-tu lu l'article qui parle?

by whom have-you read the=article that talks 
(X7) a. Hector était propriétaire de plusieurs maisons, qu'il avait achetées à des époques différentes. Ses héritiers essayent d'identifier les propriétés à partir de photos. Ils se penchent sur la photo d'une belle maison art déco et demandent au notaire :

'Hector used to own several houses, which he had bought at different times. His heirs try to identify the ownders from photographs. They consider the photo of a beautiful art deco house, and ask the solicitor:'

b. Quand est-ce que c'est la maison qu'il a achetée? when is-it that it=is the house that=he has bought

(X8) a. Claire et Claude parlent du peintre Manette, dont les portraits semblent être inspirés de membres de leur famille. Jacqueline a entendu une bribe de la conversation. Intriguée, elle demande : 'Claire and Claude are discussing the painter Manette, whose portraits seem to have been inspired by members of their family. Having over-heard part of the conversation, Jacqueline, intrigued, asks:'

b. A qui a-t-il peint le portrait qui ressemble? to whom has-he painted the portrait that resembles

(X9) a. Zoé demande à sa maîtresse :

'Zoe asks her school teacher:'

b. Pourquoi les choux sont-ils verts ?

why the cabbages are-they green

'Why are cabbages green?'

(X10) a. Jaco se désespère de ne pas trouver un article qu'elle avait laissé sur la table du salon. Elle s'indigne :

'Jaco is loosing hope of finding a paper she had left on the sitting room table. She is outraged:'

b. Qui a mis de l'ordre dans mon beau désordre? who has put PARTITIVE the=order in my beautiful mess 'Who has tidied up my beautiful mess?'

(X11) a. Le docteur Pox explique à son patient les risques du voyage qu'il veut entreprendre. Le patient demande :

'Doctor Pox explains to his patient the risks associated with the trip he is hoping to make. The patient asks:'

b. Quels sont les virus les plus dangereux ?

which are the viruses the most dangerous

'What are the most dangerous viruses?' 
(X12) a. Le garagiste demande à mademoiselle Violette :

'The mechanic asks miss Violette:'

b. Où sont passés les clés anglaises ?

where have gone the keys English

'Where have the spanners gone?'

(X13) a. Ursule explique à Joseph comment elle compte lui faire parvenir des messages en lançant des bouteilles à la mer. Intrigué, Joseph demande :

'Ursule explains to Joseph how she intends to get messages to him by throwing bottles into the see. Intrigued, Joseph asks:'

b. Comment veux-tu que je te réponde?

how want-you that I you answer

'How could I possibly answer that?'

(X14) a. Arthur se méfie de sa femme. Il demande à Ernestine :

'Arthur doesn't trust his wife. He asks Ernestine:'

b. A quelle heure est-elle sortie de chez toi ?

at what hour is-she come.out of at you

'What time did she leave your place?'

(X15) a. Matthieu se promène avec un ami dans le bois derrière sa maison. L'ami est un peu perdu et ne reconnait rien. Matthieu lui montre un chemin sur leur droite et dit :

'Matthieu is taking a walk with a friend in the wood behind his house. His friend is a bit lost and doesn't recognise anything. Matthieu points to a path on the right and says:'

b. C'est le chemin qu'on l'a pris déjà ce matin. that=is the path that=one it=has taken already this morning

(X16) a. On a mis les petites filles en rang et on leur a posé des questions. Au moment de l'évaluation, les inspecteurs n'arrivent pas à s'accorder sur qui a bien répondu. L'un d'eux insiste :

'The little girls have been made to stand in line and asked some questions. When evaluation time comes, the inspectors cannot agree on who answered correctly. One of them insists:'

b. C'est la première qu'elle a bien répondu.

it=is the first.one that=she has well answered

(X17) a. Marcel veut envoyer une carte à son patron. Il a longuement discuté avec la dame du magasin pour lui expliquer le style qu'il 
cherche. Elle lui dit :

'Marcel wants to send his boss a card. He has been discussing it with the shop lady, to explain the style he is after. She tells him:'

b. On a une carte que elle pourrait convenir. one has a card that it could do

(X18) a. La maîtresse cherche une nouvelle méthode pour décourager les enfants de sa classe de mal se comporter. Elle leur annonce :

'The school teacher is looking for a new method to discourage the children in her class from misbehaving:'

b. Ce matin, on lavera celui qui rouspète un mensonge. this morning one wash.FUT.3.SG the.one who complains a lie

(X19) a. Emilie voit un grand chien noir dans la rue. Etonnée, elle se tourne vers sa tante et s'exclame :

'Emilie sees a big black dog in the stree.' Surprised, she turns to her aunt and exclaims:'

b. C'est le chien que je l'ai vu chez toi. it $=$ is the dog that I it=have seen at you

(X20) a. Lucas essaye de faire un tour de magie pour ses amis. Il annonce: 'Lucas tries to perform a magic trick for his friends. He announces:'

b. Il y a un truc dont je le connais. PRESENTATIVE a trick of.which I it know

(X21) a. Deux mamans inquiètes discutent à la sortie de l'école. 'Two worried mums are chatting after school drop-off.'

b. Est-ce qu'ils t'ont dit qui, dans ton quartier, is-it that=they to.you=have said who in your neighbourhood avait un casier judiciaire?

had a record criminal

'Have they told you who, in your neighbourhood, has a criminal record?'

(X22) a. Myriam a entendu un bruit suspect ce matin. Elle demande à son mari :

'Myriam heard a strange noise this morning. She asks her husband:'

b. Est-ce que tu sais qui, ce matin, est sorti par la is-it that you know who this morning is exited through the porte de derrière ?

door of back

'Do you know who left through the back door this morning?' 
(X23) a. Depuis qu'elle est pensionnée, la soeur d'Armande voyage sans arrêt. Armande, amusée, en parle avec une amie. Elle dit : 'Since retiring, Armande's sister has been traveling non-stop. Amused, Armande is talking about it with a friend. She says:'

b. Je me demande où, cette semaine, elle a bien pu aller. I REFL wonder where this week she has well could go 'I wonder where she might have gone this week.'

(X24) a. Les employées de la poste s'inquiètent pour leur avenir. On parle de licenciements. Julie a parlé avec la chef de service pendant la pause-café. En revenant dans son bureau, elle annonce à son collègue :

'The post office employees are worried about their future. There have been talks of redundancies. Julie has had a chat with the team manager during the break. Back in her office, she tells her colleague:'

b. Elle m'a dit qu'elle savait ce que demain on nous she to:me=has said that=she knew it that tomorrow one to.us annoncera.

announce.FUT.3.SG

'She told me she know what will be announced to us tomorrow.'

(X25) a. Julie est déprimée. Elle est allée voir un psychologue. Elle lui explique :

'Julie is depressed. She's been to see a psychologist. She explains to him/her:'

b. Il y a un truc que, dans mon travail, j'aime pas du PRESENTATIVE a thing that in my work $\mathrm{I}=$ love not of tout.

all

'There's something I really dislike in my work.'

(X26) a. Miss Marple est allée interroger la concierge sur les habitudes étranges de la locataire du deuxième étage. La concierge lui dit, d'un ton inquiet :

'Miss Marple is interviewing the porter on the strange habits of the second floor tenant. The porter tells her, on a worried tone:'

b. Elle a un chien qui, le soir, se transforme en chat. she has a dog who the evening REFL transforms into cat 'She has a dog that turns into a cat a night.' 
(X27) a. La maman de Zéphir montre à une amie un vélo rouge dans la vitrine. Elle lui dit :

'Zephir's mum shows her friend a red bike in the shop window. She tells her:'

b. Voilà le vélo que depuis toujours il rêve d'essayer. PRESENTATIVE the bike that since ever he dreams to=try.INF 'That's the bike he's always dreamt of trying.'

(X28) a. Bruno est figurant dans un film à petit budget. Il raconte à son ami Nicolas :

'Bruno is an extra in a small-budget movie. He tells his friend Nicolas:'

b. On jouait dans un film que, dans quelques années, one play.IMP.3.SG in a movie that in some years personne ne regardera plus.

nobody NEG watch.FUT.3.SG anymore

'We were acting in a movie that no one will watch anymore in a few years.'

(X29) a. Anne essaye d'organiser un souper pour l'anniversaire du patron de son mari, qui est un homme fort pris. Elle lui dit, perplexe :

'Anne is trying to organise an evening meal for the birthday of her husband's boss (who is a very busy man). At a loss, she tells him:'

b. Je me demande quand, ton patron, on pourra

I REFL wonder when your boss one manage.FUT.3.SG

l'inviter.

him=invite.INF

(X30) a. Très fier, Yakari explique à son ami Graine-de-Bison :

'A very proud Yakari explains to his friend Graine-de-Bison:'

b. J'ai vu où, le loup, ils l'ont traqué.

I-have seen where the wolf they him=have hunted.down

(X31) a. Après les essais de vol, on analyse les données pour évaluer la performance de l'apprenti-pilote. On remarque quelques écarts étranges, et on suspecte que quelque chose a dérangé le pilote pendant le vol simulé. L'analyste demande au co-pilote :

'After the flight trials, the data is being analysed to assess the performance of the trainee pilot. Some strange, sudden change of direction are noticed, and disturbance of the pilot during the simulation flight is suspected. The analyst asks the co-pilot:' 
b. Tu as vu qui, le pilote, l'a fait sursauter? you have seen who the pilot him=has made jump

(X32) a. Le policier raconte fièrement à sa femme comment ils ont fini par capturer un des associés d'Al Capone :

'The policeman proudly relates to his wife how they managed to capture one of Al Capone's associates:'

b. Tu sais quand le voleur, on l'a surpris ? you know when the thief one him=have caught

(X33) a. Joséphine a préparé une surprise pour ses clientes : elle compte se déguiser en Gollum. Une de ses amies est dans le coup et a raconté la farce à son mari. Il lui demande :

'Josephine has prepared a surprise for her clients: she intends to fancy-dress as Gollum. One of her friends is in the know, and has told her husband about the prank. He asks her:'

b. Elle t'a dit quand, ses clientes, elle comptait les she to.you=has said when her clients she intended them surprendre?

surprise.INF

(X34) a. Il n'y a plus qu'une secrétaire dans la petite firme, et tout le monde se l'arrache. Elsa demande à la patronne :

'There's only one secretary left in the small business, and everyone wants her. Elsa asks her boss:'

b. Elle t'a dit quand, les commandes, elle pourrait she to.you=has said when the orders she would.manage les passer?

them make.INF

(X35) a. On cherche des témoins pour élucider le mystère de la disparition de Marie et Lazare. Plusieurs personnes ont dit avoir aperçu Lazare, mais pas Marie. On interroge la concierge, qui répond, désolée :

'Witnesses are being sought to shed light on the mysterious disappearance of Marie and Lazare. Several persons report having seen Lazare, but not Marie. The porter is questioned, and she replies on a sorry tone:'

b. Je ne sais pas qui, Marie, l'a vue. I NEG know not who Marie her=has seen

(X36) a. Les collègues de Marie la cherchent partout. Certains disent qu'elle est venue tôt puis repartie, mais personne n'arrive à s'accorder sur 
les faits. La patronne interroge le réceptionniste, qui lui répond : 'Marie's colleagues are looking for her everywhere. Some say she came early and left, but no one agrees on the facts. The boss asks the receptionist, who answers:'

b. Je ne sais pas qui, Marie, l'a vue ce matin.

I NEG know not who Marie her=has seen this morning

(X37) a. Paola explique à son amie pourquoi elle n'aime pas travailler à l'hôpital :

'Paola explains to her friend why she doesn't like to work at the hospital:'

b. Ce qui, moi, me dérange le plus, c'est l'odeur.

that which me REFL bothers the most it $=$ is the $=$ smell

(X38) a. Pierre se vante à son ami de ses exploits et de ceux de ses frères. Il déclare :

'Pierre brags about his and his brothers' exploits in front of a friend. He declares:'

b. J'ai vu la forêt où, le loup, ils l'ont traqué. $\mathrm{I}=$ have seen the forest where the wolf they him=have hunted.down

(X39) a. Victoria feuillette un magazine avec son amie. En poussant un soupir, elle lui montre une page et dit :

'Victoria leafs through a magazine with her friend. With a sigh, she points to a page and says:'

b. Voilà le bateau qui, moi, m'a toujours fait PRESENTATIVE the boat that me REFL=has always made rêver.

dream

(X40) a. Flore a surpris Paul en train de commettre un crime dans un hôtel de Belgrade. La police locale essaye de l'interroger via un interprète, et lui demande s'il a pu s'échapper par l'escalier de service. Mais Flore ne peut pas les renseigner. L'interprète explique aux policiers :

'Flore has caught Paul in the middle of a crime in a Belgrade hotel. The local police attempts to question her via an interpreter, and asks her if he managed to escape through the back stairs. But Flore cannot tell them. The interpreter explains to the police:'

b. Elle ne connait pas l'hôtel où, Paul, elle l'a surpris. she NEG knows not the=hotel where Paul she him=has caught 
(X42) a. Cécile est à un colloque dans le nord de la Norvège, et elle cherche un endroit où manger des sushi le dimanche après-midi. Mais tous les restaurants sont fermés. Elle interroge Sharon, qui lui répond : 'Cecile is at a conference in the North of Norway, and she's looking for a place to have sushi on a Sunday afternoon. But all the restaurants are closed. She asks Sharon, who answers:'

b. Je ne connais pas d'hôtel où, des sushi, tu pourrais I NEG know not of=hotel where INDEF sushi you could en manger.

PARTITIVE eat

'I don't know of any hotel where you could eat sushi.'

(X43) a. Après avoir montré les médailles d'or au maire, le guide le conduit dans le gymnase et lui désigne un petit groupe qui travaille aux barres parallèles. Il chuchote :

'After having shown the gold medals to the mayor, the guide takes him to the gymnasium and shows him a small group training on the parallel bars. He whispers:'

b. Voici les athlètes qui, les médailles d'or, les PRESENTATIVE the athletes who the medals of=gold them ont remportées.

have won 'Here are the gold medals that the athletes have won.'

(X44) a. L'équipe de gymnastique de Lyon a remporté 3 médailles d'or aux jeux olympiques, contre toute attente. Elles sont exposées dans le hall du gymnase, qui est ouvert aux visiteurs. Le guide s'arrête devant avec un petit groupe et annonce fièrement :

'Lyon's gymnastics team has won 3 gold medals at the Olympic games, against all odds. They are displayed in the gymnasium, which is open to visitors. The guide stops by with a small group and proudly announces:'

b. Voici les médailles que, les athlètes, ils sont fiers PRESENTATIVE the medals that the athletes they are proud d'avoir remportées.

to $=$ have.INF won

'Here are the medals that the athletes have won.'

(X45) a. Sophie consulte un psychologue avec sa fille, qui fait de terribles cauchemars. Ses amies savent que la petite a eu peur d'un des locataires du bloc d'appartements où elles habitent. L'une d'elle 
commente :

'Sophie is seeing a psychologist with her daughter, who is having terrible nightmares. Her friends know that the little one got scared by one of the tenants from the block they live in. One of them comments:'

b. Elle n'a jamais dit qui, sa petite fille, l'avait tant she $\mathrm{NEG}=$ has never said who her little girls her=had so effrayée.

frightened

'She never said who scared her little girls so much.'

(X46) a. Luc voudrait que sa mère lui achète des bottes. Il essaye de lui expliquer le modèle qu'il convoite :

'Luc would like her mother to buy him boots. He tries to explain to her the type he fancies:'

b. Tu sais, les énormes bottes comme Jean-Marc, il a. you know the enormous boots like Jean-Marc he has 'You know; the huge boots like those of Jean-Mark.'

(X47) a. Arthur explique à son fils les jalousies qui opposent les différent corps de métier avec lesquels il travaille :

'Arthur explains to his son the jealousies that oppose the different trades he is working with:'

b. Tu sais qui les plombiers, ils envient? 'Do you know who you know who the plumbers they envy the plumbers envy?'

(X48) a. Tom rêve d'entrer à l'école du cirque. Il demande à sa maman : 'Tom dreams to get into the circus school. He asks his mum:'

b. $\mathrm{Tu}$ sais comment les équilibristes, ils arrivent à marcher you know how the equilibrists they manage to walk sur un fil ? 'Do you know how equilibrists manage to walk on on a string a tightrope?'

(X49) a. Jaco enregistre le petit Léo, qui est fasciné par l'enregistreur. Léo lui demande ce que c'est, cette drôle de machine, et à quoi elle sert. Jaco répond :

'Jaco is recording little Leo, who is fascinated by the recorder. Leo asks her what that strange machine is, and what it is for. Jaco answers:' 
b. Elle enregistre ce que toi, tu dis. she records that that you you say 'It records what you say.'

(X50) a. Le coiffeur Léon se remémore la clientèle bigarrée qu'il avait il y a quelques années. Il explique à un ami :

'Leon's hairdresser remembers the colourful clients she used to have a few years ago. He explains to his friend:'

b. J'avais un philosophe, un type dont la matière principale, $\mathrm{I}=$ had a philosopher a guy whose matter principal it=is c'est la philosophie.

the philosophy

'I know a philosopher; a guy whose main topic is philosophy.'

(X51) a. Certaines rues du quartier des Trois Mégots sont devenues dangereuses. Dans une des rues, le facteur refuse de faire sa tournée. Dans une autre, c'est le laitier. Madame Machin, interrogée par une assistante sociale qui connaît bien le quartier, lui déclare : 'Some streets in the Trois Megots area have become unsafe. The postman is refusing to deliver mail to one of these streets. Mrs Machin, interrogated by a social worker who knows the areas well, declares:'

b. J'habite la rue où, le laitier, il refuse de venir. I=live the street where the milkman he refuses to come 'I live in the street the milkman refuses to come to.'

(X52) a. Marie retrouve son amie Agnès et veut la féliciter du succès de son mari David, qui s'est lancé depuis peu dans la photographie. Enthousiaste, elle lui annonce :

'Marie is meeting up with her friend Agnes and wants to congratulate her for the success of her husband David, who has recently become a photographer. Enthusiastic, she announces:'

b. J'ai vu l'exposition que ton mari, il organise. $\mathrm{I}=$ have seen the=exhibition that your husband he organises 'I've seen the exhibition your husband is organising.'

(X53) a. Louis veut inviter Amandine à aller prendre un verre. Il lui demande où elle aimerait aller. Elle ne connaît pas bien la ville mais lui suggère :

'Louis wants to invite Amandine out for a drink. He asks her where she would like to go. She doesn't know the town well but suggests to him:' 
b. J'aime le café où tes collègues, ils m'ont emenée. $\mathrm{I}=$ like the cafe where your colleagues they me=have taken 'I like the cafe your colleagues took me to.'

(X54) a. Gaston et ses amis font une chasse au trésor dans un grand château. Ils entendent un autre groupe d'enfants à l'étage et se demandent comment les y rejoindre. Tout à coup, ils trouvent un escalier dont ils ignoraient l'existence. Excité, Gaston déclare :

'Gaston and his friends are doing a treasure hunt in a big castle. They hear another group of children upstairs and wonder how to join them there. Suddenly, they find some stairs they didn't know existed. Excited, Gaston declares:'

b. Ca doit être l'escalier que les autres, ils ont pris. that must be the=stairs that the others they have taken 'That must be the stairs that the others have used.'

(X55) a. Madame Hanne a fait des pommes au four. Avec un grand sourire, elle déclare à Jacqueline :

'Mrs Hanne has baked some apples. With a big smile, she declares to Jacqueline:'

b. C'est le dessert que les enfants, ils aiment le mieux. it $=$ is the dessert that the children they love the best 'That's the dessert children love most.'

(X56) a. Francis et Léa planchent sur un exercice de math qu'ils n'arrivent pas à terminer. Francis va trouver son père pour lui demander de l'aide :

'Francis and Lea are struggling with a maths problem they are not able to complete. Francis goes and finds his father to ask him for help:'

b. Voilà un exercice que nous, on n'arrive pas à PRESENTATIVE an exercise that we $3 \mathrm{SG}$ NEG=manage not to faire.

do

'Here's an exercise we're not managing to do.'

(X57) a. Le ministre de la culture parle avec un de ses amis journalistes : 'The culture minister is talking with a friend who is a journalist:'

b. Tu sais qui le monde entier nous envie ? you know who the world whole us envies 'Do you know who everyone envies us for?' 
(X58) a. Pauline s'inquiète de devoir passer une soirée à l'opéra avec les collègues de sa soeur et quelques autres. Anxieuse, elle demande à sa soeur :

'Pauline worries about having to spend an evening at the opera with her sisters' colleagues and a few other people. Anxious, she asks her sister:'

b. Je peux te demander qui tes collègues veulent inviter?

I can to.you ask who your colleagues want invite.INF 'Can I ask you whom your colleagues want to invite?'

(X59) a. Natacha doit vider le grenier de sa grand-mère. Elle fait l'inventaire avec une amie, qui lui demande :

'Natacha has to empty her grand-mother's attic. She takes the inventory with a friend, who asks her:'

b. As-tu songé à qui ces vieux objets feraient have=you thought to whom these old objects would=make plaisir? pleasure 'Have you thought who might like these old things?'

(X60) a. Carine cherche ses enfants dans le jardin. Elle dit : 'Carine is looking for her children in the garden. She says:'

b. Je me demande où Sébastien a bien pû passer.

I REFL ask where Sebastien has well can go 'I wonder where Sebastien is.'

(X61) a. Une journaliste est venue à l'école pour enregistrer des témoignages d'enfants. A une petite fille qui lui demande pourquoi la journaliste a un micro, la prof répond :

'A journalist has come to school to record children's testimonies. To a little girl who asks her why the journalist has a microphone, the teacher answers:'

b. Elle enregistre ce que les enfants disent. she records that that the children say 'It records what the children say.'

(X62) a. L'histoire du vol des bijoux de Bianca a fait la une de tous les journaux. Enervé, son imprésario montre la dernière édition au chauffeur :

'The news of Bianca's jewels theft is on all the newspapers' frontpages. Annoyed, her agent shows the latest edition to the driver:' 
b. $\mathrm{Tu}$ as $\mathrm{vu}$ ce que les journalistes ont fait de you have seen that the journalists have done of this cette histoire?

story

'Have you seen what the press has made of this story?'

(X63) a. Loreline a besoin d'aide pour transporter son piano électrique. Elle téléphone au frère de son ami Nicolas et lui explique où elle habite. C'est une petite rue très étroite et en pente, difficile pour les apprenti-conducteurs. Elle dit :

'Loreline needs help to transport her electric piano. The call her friend Nicolas' brother and explains where she lives. It is a very narrow and steep street, difficult to reach by learner-drivers. She says:'

b. J'habite la rue où Nicolas refuse de se parquer. $\mathrm{I}=$ inhabit the street where Nicolas refuses to REFL park 'I live in the street where Nicolas refuses to park (his car).'

(X64) a. Chloé essaye de convaincre une cliente de la valeur d'une poupée qu'elle hésite à acheter. Elle lui dit :

'Chloe is trying trying to impress upon a client the value of a doll she's hesitating to buy. She tells her:'

b. C'est une poupée que les collectionneurs s'arracheraient. 'It's a it $=$ is a doll that the collectors $\quad$ REFL $=$ snatch doll collectors would fight for.'

(X65) a. Jacques essaye de retenir Maddy en lui faisant des promesses. Il lui promet :

'Jacques is trying to keep Maddy with promises. He offers:'

b. Jete donnerai des bijoux que la reine t'envierait.

I to.you will=give INDEF jewels that the queen you=would.envy 'I will give you jewels that the queen would envy you for.'

(X67) a. Zoé est impatiente de rencontrer le patron de son mari, qui leur a promis de les inviter à l'opéra il y a quelques semaines. Rêveuse, elle dit à son mari :

'Zoe is looking forward to meeting her husband's boss, who had promised to invite them to the opera a few weeks ago. Dreamy, she tells her husband:'

b. Je me demande quand, ton patron, il va nous inviter. I REFL ask when your boss he will us invite 'I wonder when your boss will invite us.' 
(X68) a. Le cardinal s'indigne devant le manque de respect dont le portier lui a fait preuve. Il explose :

'The Cardinal is outraged by the lack of respect shown to him by the doorman. He bursts out:'

$\mathrm{Au}$ pape, personne n'oserait lui parler ainsi.

to.the pape nobody $\mathrm{NEG}=$ would.dare to.him talk so

'No one would dare speak like that to the pope.' 